tained by cooling the same solution from $50^{\circ}$ to room temperature contained $5 \mathrm{I} .9$ per cent. $\mathrm{C}_{2} \mathrm{O}_{4}$. As the oxalates described by Souchay and Lensson would contain 4 I.9 per cent. and 49 per cent. $\mathrm{C}_{2} \mathrm{O}_{4}$ respectively, it seems probable that the precipitates from the more saturated solutions are mixtures of the double salt described above and potassium oxalate.

CHEMICAL LABORATORY UNIVERSITY OF TORONTO, May, I903.

\title{
A NEW DOUBLE OXALATE OF BISMUTH AND AMMONIUM.
}

By F. B. Allan AND T. A. Phillips.

Received May 20, 2903.

SoUCHAY AND LFNSSON ${ }^{1}$ dissolved bismuth oxalate in concentrated, hot ammonium oxalate solution and obtained, on cooling, a double salt to which they gave the formula

$$
\mathrm{Bi}_{2}\left(\mathrm{C}_{2} \mathrm{O}_{4}\right)_{3} 9\left(\mathrm{NH}_{4}\right)_{2} \mathrm{C}_{2} \mathrm{O}_{4} 24 \mathrm{H}_{2} \mathrm{O} \text {. }
$$

Their analyses do not agree very closely with that formula, and as some experiments made in this laboratory threw doubt on the existence of this complex double salt, their work has been repeated.

A 4 per cent. solution of ammonium oxalate was boiled with bismuth oxalate, using a reflux condenser, for about half an hour. and filtered hot. On cooling, this solution deposited small, white crystals which were dried, under pressure, between paper. The salt. was easily soluble in hydrochloric acid. The bismuth was determined as the sulphide, the oxalic acid by titration with permanganate, and the ammonia distilled over by boiling with potash. absorbed in hydrochloric acid and determined in the usual way.

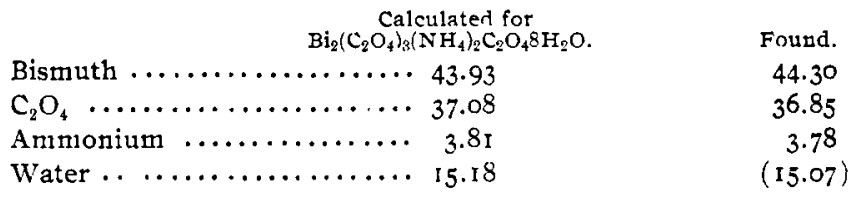

Bismuth oxalate is only slightly soluble in ammonium oxalate, and large quantities of the solution must be used in preparing the double salt, so that imperfect filtering or the slight solubility of basic salt formed during the boiling would account for the high value found for bismuth and the corresponding low values for oxalic acid and ammonia.

1 Ann. Chem. (Liebig), $105,245$. 
More of the double salt was prepared by using ammonium oxalate solution saturated at $25^{\circ}$. The precipitate deposited at $50^{\circ}$ gave 3.85 per cent. of ammonia and was, therefore, the same compound as the first, but when this solution cooled to room temperature, it yielded two kinds of crystals. which, under the microscope, were identified as the double salt and ammonium oxalate, and it would appear that the salt described by Souchay and Lensson was a similar mixture.

CEEMICAL LABORATORY, CNIVERSITY OF TORONTO, May, IyO3.

\section{DOUBLE HALIDES OF TELLURIUM WITH THE ALKA- LOIDS.}

BY VICTOR LENHER AND WINIFRED TITUS.

Received April 27, 2903 .

It has been previonsly shown ${ }^{1}$ that the chloride and bromide of tellurium unite with the salts of the amines to form a series of double salts in which the types of $\mathrm{H}_{2} \mathrm{TeCl}_{6}$ and $\mathrm{H}_{2} \mathrm{TeBr}_{8}$ are consistently followed. The hydrogen of these acids may be considered as having been directly replaced by the complex ammonium group, or the tellurium halide may be looked at as uniting with the molecules of the hydrochloride or hydrobromide of the amine.

Following the same line of work with the alkaloids, there appear types which differ considerably from the first or most simple type.

In some cases I molecule of the alkaloid unites with I molecule of $\mathrm{H}_{2} \mathrm{TeCl}_{\mathrm{B}}$ or $\mathrm{H}_{2} \mathrm{TeBr}_{\mathrm{B}}$ while in others 2 molecules of the alkaloids unite with I molecule of the tellurium halogen acids. As a rule, the salts appear to follow the type of compounds that $\mathrm{H}_{2} \mathrm{PtCl}_{8}$ forms with the alkaloids, for example, with quinine there appear the salts $\mathrm{C}_{20} \mathrm{H}_{24} \mathrm{~N}_{2} \mathrm{O}_{2} \mathrm{H}_{2} \mathrm{PtCl}_{6}+\mathrm{H}_{2} \mathrm{O}$ and $\mathrm{C}_{20} \mathrm{H}_{24} \mathrm{~N}_{2} \mathrm{O}_{2} \mathrm{H}_{2} \mathrm{TeCl}$, while with morphine $\left(\mathrm{C}_{17} \mathrm{H}_{19} \mathrm{NO}_{3}\right)_{2} \mathrm{H}_{2} \mathrm{TeCl}_{6}$ is analogous to $\left(\mathrm{C}_{17} \mathrm{H}_{19} \mathrm{NO}_{3}\right)_{2} \mathrm{H}_{2} \mathrm{PtCl}_{6}+6 \mathrm{H}_{2} \mathrm{O}$.

However, the chloroplatinate usually crystallizes with water of crystallization while these new compounds are anhydrous.

The method of procedure for the formation of these compounds consists in adding a strong solution of tellurium dioxide in hydrochloric or hydrobromic acid to a concentrated solution of the alkaloid in the corresponding acid.

I This Journal, 22, 136 . 